\title{
The influence of grazing and cultivation on runoff, soil erosion, and soil nutrient export in the central highlands of Ethiopia
}

\author{
${\text { Zenebe Adimassu }{ }^{1 *}, \text { Lulseged Tamene }^{2} \text { and Degefie T. Degefie }}^{3}$
}

\begin{abstract}
Background: Grazing by livestock and cultivation have been considered as two important causes of soil erosion and nutrient export. However, there has been limited evidence that grazing or cultivation matters to soil erosion and nutrient export in Ethiopia. Hence, this study was conducted in the Galesa watershed in Ethiopia to examine the effects of grazing and cultivation on runoff, soil loss, and nutrient export. Daily values of runoff, soil erosion, and nutrient outflow were measured for three consecutive years following standard procedures. Independent $t$ test was performed to check if the means of runoff, soil loss, and nutrient loss from grazing and cultivated lands were significantly different. Moreover, repeated analysis of variance (ANOVA) was used to test if mean values of runoff, soil loss, and nutrient export varied significantly over the study years.

Results: Although the average annual runoff depth was 7.8\% higher in grazing land (GL), soil erosion was significantly lower (39\%) in GL as compared to cultivated land (CL). Similarly, sediment and runoff-associated annual losses of total nitrogen (N), available phosphorus (P), exchangeable potassium (K), and organic carbon (OC) were low in the GL treatments. Lowest losses of total $N\left(9.30 \mathrm{~kg} \mathrm{ha}^{-1} \mathrm{year}^{-1}\right)$, available P $\left(0.83 \mathrm{~kg} \mathrm{ha}^{-1} \mathrm{year}^{-1}\right)$, and exchangeable $\mathrm{K}\left(1.84 \mathrm{~kg} \mathrm{ha}^{-1} \mathrm{year}^{-1}\right)$ were recorded in $\mathrm{GL}$ treatment. Likewise, lowest losses of sediment-associated total N (32.8 kg ha $\left.\mathrm{year}^{-1}\right)$, available $\mathrm{P}\left(0.39 \mathrm{~kg} \mathrm{ha}^{-1} \mathrm{year}^{-1}\right)$, exchangeable $\mathrm{K}\left(0.23 \mathrm{~kg} \mathrm{ha}^{-1} \mathrm{year}^{-1}\right)$, and soil organic carbon $\left(630 \mathrm{~kg} \mathrm{ha}^{-1}\right.$ year $\left.^{-1}\right)$ were recorded from GL over the 3 years of experimentation.

Conclusion: Our results indicate that cultivation increased soil erosion as compared to grazing. Although there were significant reductions in soil erosion and nutrient export from grazing lands compared with cultivated lands, the absolute losses were still high. This implies the need for grazing land management using appropriate physical and biological erosion control measures to increase productivity and reduce soil erosion as well as nutrient export.
\end{abstract}

Keywords: Cultivation, Land degradation, Runoff coefficient, Soil erosion, Soil nutrient export, Tillage

\section{Introduction}

More than $80 \%$ of the total population of Ethiopia is engaged in agricultural activities (CSA 2012). However, the Ethiopian agricultural economy, which is the mainstay of the vast majority of its population, is under continuous threat from various forms of land degradation. Among these, soil erosion by water and nutrient export are the most important ones resulting in low agricultural

\footnotetext{
* Correspondence: Zenebeteferi@yahoo.com

${ }^{1}$ International Water Management Institute (IWMI), Addis Ababa, Ethiopia

Full list of author information is available at the end of the article
}

productivity (Blaikie 1985; Hurni 1989; Shiferaw and Holden 2000; Nyssen et al. 2004; Descheemaeker et al. 2006; Gessesse et al. 2015; Meten et al. 2015; Miheretu and Yimer 2017). Ethiopia has been described as one of the countries in the world with the most serious soil erosion, with an estimated total annual soil loss ranged from $16 \mathrm{t} \mathrm{ha}^{-1}$ year $^{-1}$ (Gebreegziabher et al. 2008) to 179 $\mathrm{t} \mathrm{ha}^{-1}$ year $^{-1}$ (Shiferaw and Holden 1999) in croplands. Besides soil losses, runoff and nutrient losses are important production constraints for crop production. Loss of rainwater as runoff limits water available for crop
Springer Open (c) The Author(s). 2020 Open Access This article is licensed under a Creative Commons Attribution 4.0 International License, which permits use, sharing, adaptation, distribution and reproduction in any medium or format, as long as you give appropriate credit to the original author(s) and the source, provide a link to the Creative Commons licence, and indicate if changes were made. The images or other third party material in this article are included in the article's Creative Commons licence, unless indicated otherwise in a credit line to the material. If material is not included in the article's Creative Commons licence and your intended use is not permitted by statutory regulation or exceeds the permitted use, you will need to obtain permission directly from the copyright holder. To view a copy of this licence, visit http://creativecommons.org/licenses/by/4.0/. 
production and groundwater recharge (Rao et al. 1998; Nyssen et al. 2005). Nutrient export from agricultural land represents an economic loss to the farmer and may contribute to water pollution in the downstream water bodies (Mwendera and Saleem 1997; Mwendera et al. 1997). Some evidence shows that soil erosion is costing the Ethiopian economy about 4.3 billion USD per year (Gebreselassie et al. 2016). This means that there is an urgent need to tackle the problem of soil erosion and restore degraded areas to enhance overall system productivity. The major drivers of land degradation in the country include increasing human and livestock population pressure, inappropriate land use, and poor management of land and water resources (Tolessa et al. 2018; Shiferaw and Holden 2000).

Among others, overgrazing by livestock has been considered as one of the most important causes of soil erosion and nutrient export in Ethiopia (German et al. 2006; German et al. 2008; Thornes 2007; Bezabih et al. 2014; Bedasa and Hussein 2018; Terefe et al. 2020). However, runoff, soil, and nutrient losses are highly variable due to variations in land use, topographic, edaphic, and climatic factors (Belayneh et al. 2019; Melak et al. 2019). Although some studies showed that gully formation is more common in grazing areas, mainly due to overgrazing and preferential management of cultivated areas by farmers (Tamene et al. 2017; Tamene et al. 2006), there is limited information on whether grazing or cultivation reduces runoff, soil loss, and nutrient export in Ethiopia (Mekuria et al. 2007; Harweg and Ludi
1999). It will thus be important to generate quantitative evidences regarding grazing and cultivated lands in relation to runoff, soil loss, and nutrient export. This will facilitate planning and decision-making at different levels where to focus on livestock production, crop production, or both (Alemayehu et al. 2013). Hence, the aim of this study was to assess the influence of grazing and cultivation on runoff, soil loss, and nutrient export in Ethiopian highlands.

\section{Materials and methods \\ Description of experimental site}

The Galesa watershed is located in the central highlands of Ethiopia between $09^{\circ} 06^{\prime} 54^{\prime \prime} \mathrm{N}$ to $09^{\circ} 07^{\prime} 52^{\prime \prime} \mathrm{N}$ and $37^{\circ} 07^{\prime} 16^{\prime \prime} \mathrm{E}$ to $37^{\circ} 08^{\prime} 54^{\prime \prime} \mathrm{E}$ (Fig. 1). As shown in the figure, administratively, the site is situated in the Dendi District West Shewa Zone of the Oromiya Regional State. The watershed is part of the Awash basin which covers 340 ha and supports livelihood of about 900 people belonging to 170 households (Adimassu et al. 2008). The watershed has elevations ranging from 2907 to $3089 \mathrm{~m}$ above sea level.

The farming system is typical mixed crop-livestock production system and the dominant crops grown in the area are barley (Hordeum vulgare), potato (Solanum tuberosum), and enset (Ensete ventricosum). Livestock play important roles in the farming system as a source of nutrition, income, draught power, and provide organic fertilizer (Megersa et al. 2013). Trees in the system are few and watershed residents have little

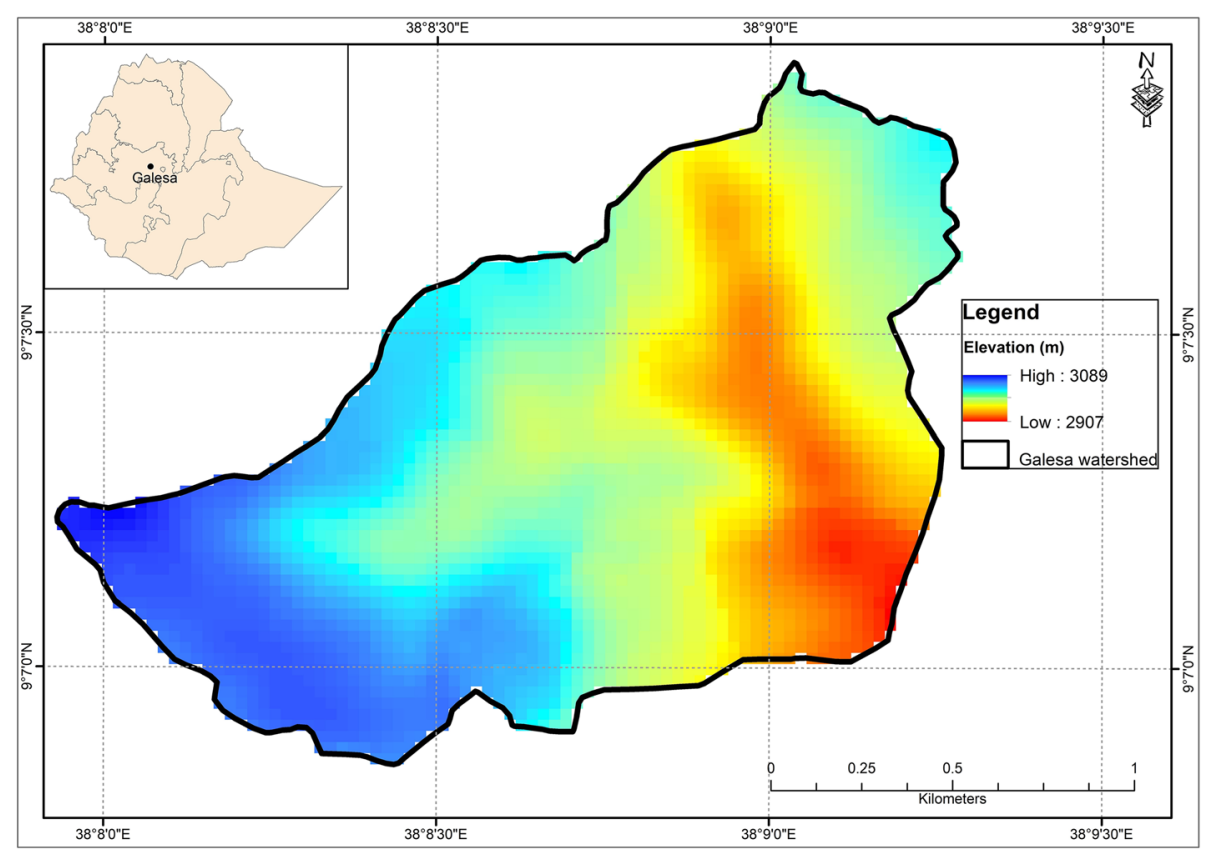

Fig. 1 Location of the study watershed 
access to remnant distant forests. As a result, animal dung isused as fuel (German et al. 2008). The soil at the experimental site is Nitisols with red, deep, and well drained characteristics. The physical and chemical properties of the soils in the experimental site are presented in Table 1 . The experiment was conducted at a clay texture soil with $63 \%$ clay content. The bulk density of the soil of the experimental land was 1.08 $\mathrm{g} \mathrm{cm}^{-3}$. As shown in Table 1 , the soil is acidic ( $\mathrm{pH}$ of $5.2)$ with low organic carbon content (2.9\%). The average total nitrogen and available phosphorus are also shown in Table 1. During the start of the main season, the ground cover of both land use types was very poor which contributed higher soil loss and runoff and nutrient export.

Rainfall data for the watershed were collected from a rainfall station installed near the experimental runoff plots. The average annual rainfall at the experimental plots during the study period was nearly 1400 $\mathrm{mm}$ with coefficient of variation of $10 \%$ (Fig. 2). There are two rainy seasons in the study area-belg and meher. Belg is a short and light rainy season usually lasts from February to April, while meher is long and the main source of rainfall, which lasts from June to September. In general, the rainfall pattern in the study site is similar to other parts of the country in which large proportion of the rainfall is concentrated in the meher rainy season (Nyssen et al. 2005; Cheung et al. 2008; Gebreegziabher et al. 2008). Accordingly, the average meher rainfall in the study area constituted $78 \%$ of total rainfall. During the 3-year study, 293 rainy days were recorded during the meher season. It was 78 rainy days $(782 \mathrm{~mm})$ in 2007, 102 rainy days $(1188 \mathrm{~mm})$ in 2008 , and 113 rainy days $(1032 \mathrm{~mm})$ in 2009.

Table 1 Physico-chemical properties of the soil at experimental site before the implementation of the study

\begin{tabular}{lc}
\hline Soil characteristics & Values \\
\hline $\begin{array}{l}\text { Soil physical properties } \\
\text { Bulk density }\left(\mathrm{g} \mathrm{cm}^{-3}\right)\end{array}$ & 1.08 \\
Particle size distribution & \\
Sand (\%) & 15.6 \\
Clay (\%) & 62.6 \\
Silt (\%) & 21.8 \\
Soil texture class & Clay \\
Soil chemical properties & \\
pH (1: 1 $\left.\mathrm{H}_{2} \mathrm{O}\right)$ & 5.21 \\
Organic carbon (\%) & 2.91 \\
Total nitrogen (\%) & 0.13 \\
Available phosphorus (ppm) (Bray II method) & 14.22 \\
\hline
\end{tabular}

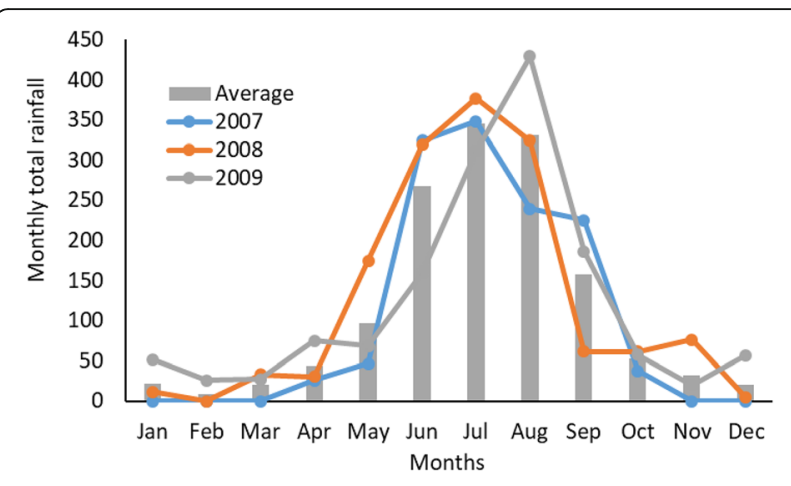

Fig. 2 Monthly rainfall distribution of the study area during the study period

\section{Experimental setup, data collection, and analysis}

Two treatments consisting of grazing land (GL) and cultivated land $(\mathrm{CL})$ with barley as a test crop were used for this experiment over 3 years. Barley variety HB 1307 with seeding rate of $175 \mathrm{~kg} \mathrm{ha}^{-1}$ was planted using broadcasting after the land was tilled three times (based on the local practices in the study area). Fertilizer was not applied to cultivated lands to avoid the confounding effects of fertilizer application on nutrient export. Treatments were replicated three times. Grazing plots were protected for 2 weeks after the onset of rainfall to allow the growth of grasses. Then after grazing, lands were grazed by livestock (mainly cattle and sheep). On average, 4 cattle and 5 sheep were grazing every 5-7 days based on the availability of grasses in the plot. The average time animals grazed were $6 \mathrm{~h}$ per day. Cattle and sheep were used for grazing in which they were the dominant livestock types in the study area. After harvesting, livestock were allowed to graze during the rest of dry season.

Six hydrologically isolated runoff plots of $35 \mathrm{~m}$ long and $6 \mathrm{~m}$ wide $\left(210 \mathrm{~m}^{2}\right)$ were laid on a uniform land slope of $16 \%$ and bounded by galvanized sheet metal of $60 \mathrm{~cm}$ wide, $15 \mathrm{~cm}$ of which was inserted into the ground to prevent lateral flow of runoff and nutrient (Fig. 3). As illustrated in the figure, the runoff sample was taken using multi-slot divisors. Accordingly, the surface runoff was collected in the first tank, which also overflows into a second tank via a multi-slot (nine-slot) that allowed the overflow into the second tank (five-slot) that also leads runoff to the last tank (Kothyari et al. 2004). The volume of runoff in each tank (box) was measured every $24 \mathrm{~h}$ (at 9:00 $\mathrm{AM}$ ) and then total runoff volume per plot was calculated.

The total amount of eroded soil was estimated by filtration of composite samples collected from both tanks after thoroughly mixing the runoff and sediment collected in them (Heron 1990; Hudson 1993). The sediment retained after filtration (paper type: Whatman No. 1 , pore size $1.2 \mu \mathrm{m}$ ) was oven-dried at $105{ }^{\circ} \mathrm{C}$ for $24 \mathrm{~h}$, weighed and compared with the weight of another filter 


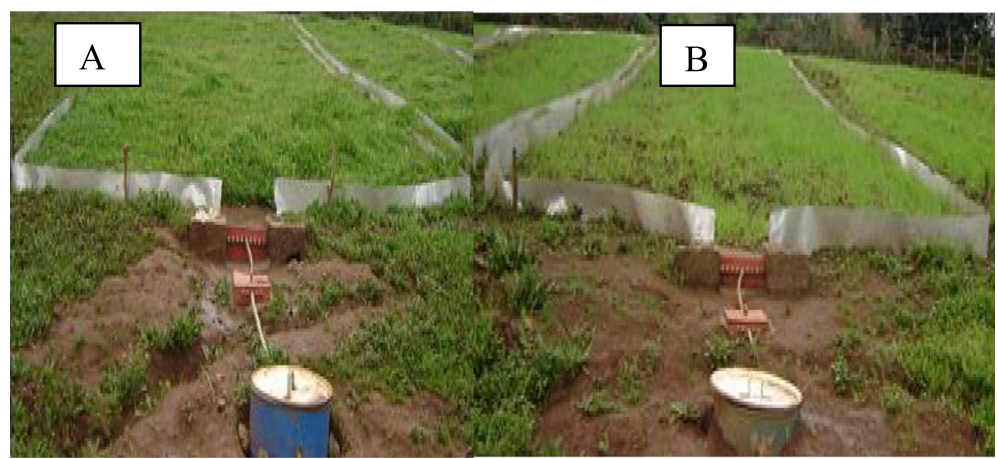

Fig. 3 Experimental setup of runoff plots with runoff collection tanks. a Grazing land and $\mathbf{b}$ cultivated land

paper of the same size, after filtration of an equal volume of pure water, as a control (Kothyari et al. 2004). Soil loss ( $t / h a)$ was calculated based on the volume of runoff and the sediment concentration. The daily soil loss from each plot was calculated by multiplying the total runoff with the sediment concentration.

Soil and runoff samples leaving each plot were taken for nutrient analysis to determine soil nutrient export associated with sediment and runoff. After thoroughly stirring the content of runoff collectors, composite samples were taken for nutrient analysis. The samples were kept in the bottles for $4-5 \mathrm{~h}$ in the laboratory at room temperature for sedimentation. After sedimentation, the topmost water in each bottle was collected for runoffassociated nutrient analyses and determination of runoff-associated nutrient outflow. The nutrient analysis from runoff was done within $24 \mathrm{~h}$. Then nutrient losses from runoff of each plot were calculated by multiplying the average concentration of each nutrient in the runoff with total runoff volume.

Similarly, the settled sediment in the containers was airdried and used for sediment associated nutrient analysis. Total $\mathrm{N}$, available $\mathrm{P}$, exchangeable $\mathrm{K}$, and organic matter $(\mathrm{OM})$ were measured from the sediment. Total nitrogen was determined using the micro-Kjeldahl method (Bremner 1965) while that of available P by Bray II method (Bray and Kurtz 1945). Exchangeable $K$ was determined by using ammonium acetate leachate method (Asadu 1996). Soil organic carbon (SOC) was determined using Walkley and Black wet digestion method (Allison 1965). The total losses of each nutrient from the sediment were calculated by multiplying the total sediment leaving each plot with the average nutrient concentration. Then, total nutrient export of each nutrient is the sum of runoff-associated and sediment-associated nutrient loss. Since laboratory analysis was expensive, soil nutrient analyses were executed only twice per season.

Finally, data from different experimental plots were analyzed separately in order to understand the effect of grazing and cultivation on runoff, soil erosion, and nutrient export. Microsoft Office Excel 2013 and Statistical Package for Social Sciences (SPSS v.17) were used to analyze the data. Independent sample $t$ test was performed to test whether the changes in runoff, soil erosion, and nutrient export were significantly different $(p<0.05)$ between grazing and cultivation. Moreover, repeated analysis of variance (ANOVA) was performed to test whether runoff, soil loss, and nutrient loss varied significantly over the years. Before analysis, assumptions of ANOVA and $t$ test including normality, equal variance (homogeneity), and independence of samples were checked.

\section{Results and discussions}

\section{Influence of grazing and cultivation on runoff}

The total values of runoff depth and runoff coefficients during the study period in different years for different treatments are shown in Table 2. Over the 3 years, an average of $281 \mathrm{~mm}$ and $259 \mathrm{~mm}$ runoff depth was generated from GL and CL, respectively. The annual runoff depth varied from $219 \mathrm{~mm}$ in 2007 from the CL treatment to $325 \mathrm{~mm}$ in 2008 from the GL treatment. The lowest annual runoff in 2007 was in response to the corresponding lower annual rainfall depth $(782 \mathrm{~mm})$. The $t$ test $(p<0.05)$ shows that significantly higher runoff was generated from GL treatment as compared to CL treatment mainly during the experiment in 2008 and 2009. The minimum runoff from CL might be due to interception and infiltration enhanced by tillage and crop cover. Higher runoff from GL might be due to low infiltration rate that can be explained in two ways. Firstly, cattle trampling during grazing may reduce infiltration. Secondly, low surface roughness resulted from lack of cultivation can contribute to low infiltration rate. Our result is in line with other studies elsewhere in Ethiopia and beyond. Adimassu et al. (2019), Gebresamuel et al. (2009), and Woyessa and Bennie (2007) reported higher runoff depths from non-tilled plots as compared to tilled plots in different parts of Ethiopia. A recent study in semi-arid Tigray region of Ethiopia also showed higher runoff production (50\%) in rangeland compared cropland (26\%) (Taye et al. 
Table 2 Runoff (mm) and runoff coefficient (\%) in grazing land (GL) and cultivated land (CL) over the three study years

\begin{tabular}{|c|c|c|c|c|c|c|c|}
\hline \multirow[b]{2}{*}{ Year } & \multirow[b]{2}{*}{ Treatments } & \multicolumn{3}{|l|}{ Runoff } & \multicolumn{3}{|l|}{ Runoff coefficient } \\
\hline & & Mean \pm SD $(\mathrm{mm})$ & $t$ & $p$ value & Mean \pm SD (\%) & $t$ & $p$ value \\
\hline \multirow[t]{2}{*}{2007} & $\mathrm{GL}$ & $234.8 \pm 9.3^{\mathrm{a}}$ & 2.37 & 0.077 & $30.01 \pm 1.19^{a}$ & 2.371 & 0.077 \\
\hline & $\mathrm{CL}$ & $218.8 \pm 7.1^{\mathrm{a}}$ & & & $27.97 \pm 0.09^{a}$ & & \\
\hline \multirow[t]{2}{*}{2008} & $\mathrm{GL}$ & $325.1 \pm 5.4^{\mathrm{a}}$ & 5.28 & 0.006 & $27.27 \pm 0.49^{\mathrm{a}}$ & 5.157 & 0.007 \\
\hline & $\mathrm{CL}$ & $305.7 \pm 3.3^{b}$ & & & $25.70 \pm 0.27^{b}$ & & \\
\hline \multirow[t]{2}{*}{2009} & $\mathrm{GL}$ & $282.0 \pm 7.3^{a}$ & 5.82 & 0.004 & $27.57 \pm 0.50^{a}$ & 6.013 & 0.004 \\
\hline & $\mathrm{CL}$ & $251.7 \pm 5.3^{b}$ & & & $24.37 \pm 0.70^{b}$ & & \\
\hline \multirow[t]{2}{*}{ Average } & $\mathrm{GL}$ & $280.7 \pm 39.6^{a}$ & 1.19 & 0.250 & $28.22 \pm 1.50^{\mathrm{a}}$ & 2.945 & 0.01 \\
\hline & $\mathrm{CL}$ & $258.7 \pm 38.4^{a}$ & & & $26.03 \pm 1.67^{b}$ & & \\
\hline
\end{tabular}

Columns with different letters are significantly different at 0.05 level, $G L$ grazing land, $C L$ cultivated land, $S D$ standard deviation

2013). Similarly, the high runoff depth from grazing land was reported in India compared with cultivated land (Rao et al. 1998). As opposed to our findings, higher runoff values were recorded from cultivated land of Tigray compared with other land use types such as grazing land, planation, and exclosure (Girmay et al. 2009). In addition, cultivated land yielded significantly higher runoff compared to the other land use types such as grazing land, exclosure, and eucalyptus plantation (Nyssen et al. 2000; Girmay et al. 2009).

As shown in Table 2, runoff coefficient varied from $24 \%$ from CL in 2009 to $30 \%$ from GL in 2007. The average runoff coefficients were 28 and $26 \%$ from GL and CL treatments, respectively. Similar to runoff, the $t$ test $(p<0.05)$ shows that the runoff coefficient from GL treatment was significantly higher compared to runoff coefficient from CL treatment during 2008 and 2009 (Table 2). Previously reported annual runoff coefficients in Ethiopia were $38 \%$ in the cultivated Vertisols of Ginchi watershed (Worku and Hailu 1999) and 40\% in the cultivated lands of Tigray (Gebresamuel et al. 2010, Gebreegziabher et al. 2008). Another study also showed that 16 to $47 \%$ of rainfall was converted into runoff in the grazing lands of Northwestern Ethiopia (Alemayehu et al. 2013). Taye et al. (2013) reported $40-50 \%$ and $15-$ $25 \%$ runoff coefficient in rangelands and croplands conserved with stone bunds, respectively, in the Tigray region of Ethiopia. In the same region, 5-21\% runoff coefficient in grazing land and $21-40 \%$ in cultivated lands were recorded (Girmay et al. 2009). Such variability in runoff coefficient might be due to variations in land use, land management practices, topography, soil and rainfall characteristics, and scale of measurement.

Table 3 shows the results of repeated ANOVA regarding the variability of runoff over the 3-year study. As shown in the table, runoff significantly varied over the 3 years. Accordingly, runoff in 2008 was significantly higher than the runoff in 2007 and 2009.

As shown in Fig. 4, a positive and significant correlation between rainfall and runoff was observed in both treatments across the years. Statistically significant relationships as revealed by high values of coefficients of determination $\left(R^{2}\right)$ were also derived through regression between rainfall and runoff for the two treatments. $R^{2}$ for GL was 0.8, 0.86, and 0.88 in 2007, 2008, and 2009, respectively. Similarly, $R^{2}$ for CL was $0.7,0.81$, and 0.85 , respectively. This implies that rainfall explains about 70 to $90 \%$ of the variation in runoff for both land use types. Our result is in line with the findings of Adimassu and Haile (2011) that strong relationship $\left(R^{2}=0.8\right)$ existed between rainfall and runoff with in wheat cultivation in the central highland of Ethiopia.

Table 3 Soil loss $\left(\mathrm{t} \mathrm{ha}^{-1}\right.$ ) in grazing land $(\mathrm{GL})$ and cultivated land $(\mathrm{CL})$ over the three study years

\begin{tabular}{|c|c|c|c|c|c|}
\hline Year & Treatments & Mean \pm SD $\left(\mathrm{t} \mathrm{ha}^{-1}\right)$ & $t$ & $p$ value & Change in soil loss (\%) \\
\hline \multirow[t]{2}{*}{2007} & $\mathrm{GL}$ & $31.8 \pm 2.1^{b}$ & -6.60 & 0.003 & 34.6 \\
\hline & $\mathrm{CL}$ & $42.8 \pm 2.1^{\mathrm{a}}$ & & & \\
\hline \multirow[t]{2}{*}{2008} & $\mathrm{GL}$ & $33.5 \pm 0.6^{b}$ & -7.85 & 0.001 & 48.1 \\
\hline & $\mathrm{CL}$ & $49.6 \pm 3.5^{\mathrm{a}}$ & & & \\
\hline \multirow[t]{2}{*}{2009} & $\mathrm{GL}$ & $33.7 \pm 2.6^{b}$ & -5.10 & 0.007 & 31.5 \\
\hline & $\mathrm{CL}$ & $44.3 \pm 2.5^{\mathrm{a}}$ & & & \\
\hline \multirow[t]{2}{*}{ Average } & $\mathrm{GL}$ & $32.9 \pm 1.9^{b}$ & -8.80 & 0.0001 & 38.6 \\
\hline & $\mathrm{CL}$ & $45.6 \pm 3.9^{\mathrm{a}}$ & & & \\
\hline
\end{tabular}



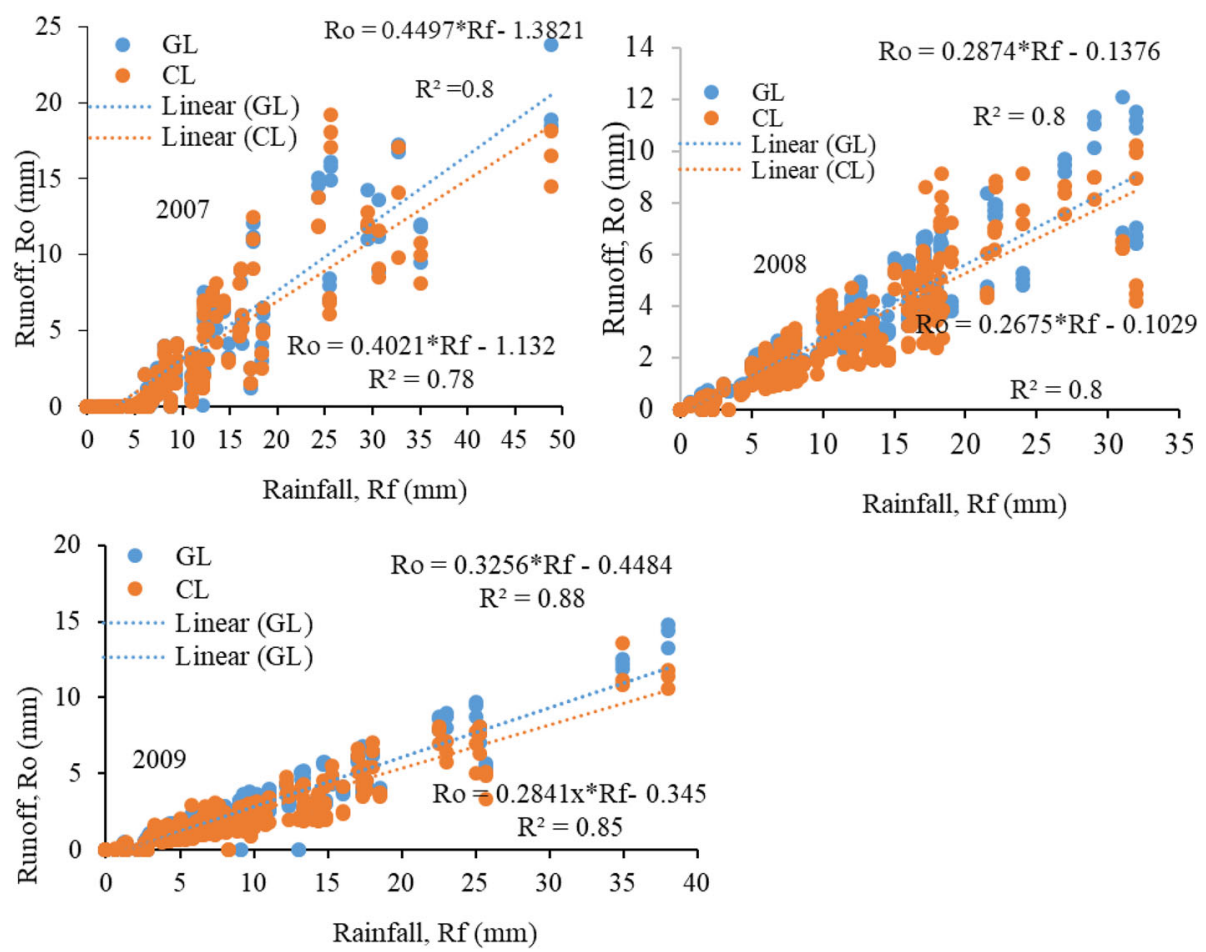

Fig. 4 Rainfall-runoff relationships in grazing land (GL) and cultivated land (CL) during the study period (2007-2009)

The rainfall-runoff relationship (Fig. 4) also shows rainfall threshold (the minimum rain depth above which runoff generation occurs) (Girmay et al. 2009; Descheemaeker et al. 2006). As shown in Fig. 4, the threshold rainfall varied across study years even with in the same land use type. Accordingly, rainfall thresholds in GL were 4.6, 2.9 , and $3.5 \mathrm{~mm}$ during 2007, 2008, and 2009 study years, respectively. Similarly, the average rainfall thresholds in CL were 4.1, 2.3, and $3 \mathrm{~mm}$ during 2007, 2008, and 2009 study years, respectively. This variation of rainfall threshold in the same land use type under different study years might be mainly attributed to variations in rainfall intensity across years.

\section{Influence of grazing and cultivation on soil losses}

Soil loss varied from $31.8 \mathrm{tha}^{-1}$ year $^{-1}$ in GL treatment in 2007 to $49.6 \mathrm{t} \mathrm{ha}^{-1}$ in CL treatment in 2008 (Table 4).

Table 4 Runoff and soil loss in grazing land (GL) and cultivated land $(\mathrm{CL})$ over the three study years

\begin{tabular}{llllll}
\hline Year & \multicolumn{2}{l}{ Runoff $(\mathrm{mm})$, mean $\pm \mathrm{SD}$} & & \multicolumn{2}{l}{ Soil loss $\left(\mathrm{t} \mathrm{ha}{ }^{-1}\right.$, mean $\left.\pm \mathrm{SD}\right)$} \\
\cline { 2 - 3 } \cline { 5 - 6 } & $\mathrm{GL}$ & $\mathrm{CL}$ & & $\mathrm{GL}$ & $\mathrm{CL}$ \\
\hline 2007 & $234.8 \pm 9.3^{\mathrm{b}}$ & $218.8 \pm 7.1^{\mathrm{b}}$ & & $31.8 \pm 2.1^{\mathrm{a}}$ & $42.8 \pm 2.1^{\mathrm{a}}$ \\
2008 & $325.1 \pm 5.4^{\mathrm{a}}$ & $305.7 \pm 3.3^{\mathrm{a}}$ & & $33.5 \pm 0.6^{\mathrm{a}}$ & $49.6 \pm 3.5^{\mathrm{a}}$ \\
2009 & $282.0 \pm 7.3^{\mathrm{b}}$ & $251.7 \pm 5.3^{\mathrm{b}}$ & & $33.7 \pm 2.6^{\mathrm{a}}$ & $44.3 \pm 2.5^{\mathrm{a}}$ \\
$p$ value & 0.015 & 0.050 & & 0.550 & 0.300 \\
\hline
\end{tabular}

Columns with different letters are significantly different at 0.05 level, $G L$ grazing land, $C L$ cultivated land, $S D$ standard deviation
Annual soil losses from GL and CL treatments are significantly different with higher soil loss $\left(45.6 \mathrm{tha}^{-1}\right)$ rates in $\mathrm{CL}$ and lower $\left(32.9 \mathrm{tha}^{-1}\right)$ rates in GL treatment. Lower soil loss in GL treatment is due to the fact that soil surface was not exposed to rainfall impact for detachment as compared to cultivated/tilled/soil surface. However, Nyssen et al. (2009) reported higher soil loss in rangelands ( $\mathrm{t} 17 \mathrm{tha}^{-1}$ year $^{-1}$ ) compared to cultivated land with stone bunds $\left(10 \mathrm{tha}^{-1}\right.$ year $\left.^{-1}\right)$ in the Tigray region of Ethiopia. This shows the positive effect of stone bunds in controlling soil erosion. Taye et al. (2013) also reported higher seasonal soil loss in rangeland (30-50 $\mathrm{t}$ ha $^{-1}$ year $^{-1}$ ) compared to cropland (6-19 tha ${ }^{-1}$ year $^{-1}$ ). Other previous studies in Ethiopia showed highly variable annual soil loss records from different land uses. For instance, Hurni (1993) reported $42 \mathrm{t} \mathrm{ha}^{-1}$ year $^{-1}$ from cultivated lands in the highlands of Ethiopia. The soil loss in cultivated lands of Tigray ranged from 17.5 to $56.7 \mathrm{tha}^{-1}$ year $^{-1}$ (Gebreegziabher et al. 2008; Girmay et al. 2009). Harweg and Ludi (1999) reported annual soil loss ranging from $2 \mathrm{t} \mathrm{ha}^{-1}$ year $^{-1}$ in Maybar to $110 \mathrm{t}$ ha $^{-1}$ year $^{-1}$ in Anjeni highlands of Ethiopia. Bosshart (1997) reported soil losses of $61 \mathrm{tha}^{-1}$ year $^{-1}$ from the cultivated catchment of Anjeni highland of Ethiopia. This variation can be explained in two ways. Firstly, there is high variation in rainfall, topography, and soil characteristics. For instance, areas in Tigray region receive lower annual rainfall compared with other 
Ethiopian highlands such as Anjeni. Secondly, it may be due to variation in the sizes of experimental plots because measuring soil loss is scale dependent (Yaekob et al. 2020; Stroosnijder 2005).

Generally, GL reduced soil loss by 35,48 , and $32 \%$ during 2007, 2008, and 2009, respectively (Table 4). The results of repeated ANOVA regarding the variability of soil loss over the 3-year study show that soil loss was not significantly different over the 3 years' period (Table 3). At plot level, this is expected as the grass layer increases surface roughness (Walle et al. 2006) and thus reduces erosion compared to the barely crop which covers the land until late $\mathrm{Au}$ gust. Similar observations were made in other studies whereby soil loss from cultivated areas was significantly higher than grazing/pastoral areas (e.g., Collins et al. 2001; Wang et al. 2003). Although there is a relatively significant soil loss reduction in grazing land compared to cultivated areas in the study area, the absolute soil loss $\left(32.9 \mathrm{tha}^{-1}\right.$ year $\left.{ }^{-1}\right)$ is still very high as compared to the maximum tolerable soil loss estimated (2-10 tha ${ }^{-1}$ year $^{-1}$ ) (Hurni and Messerli 1981). This suggests that additional soil conservation measures such as stone and soil bunds are required to reduce soil loss to acceptable limit in grazing lands.

\section{Influence of grazing and cultivation on nutrient export} Influence on sediment-associated nutrient export

The average concentrations of nutrients (nitrogen, phosphorus, and potassium) and soil organic carbon (SOC) of the sediment leaving the experimental plots are presented in Fig. 5. The results show that the concentration of total $\mathrm{N}\left(\mathrm{g} \mathrm{kg}^{-1}\right)$ ranged from 0.95 in the GL to 1.09 in the CL plots. The concentration of total $\mathrm{P}\left(\mathrm{mg} \mathrm{kg}^{-1}\right)$ ranged from 9.24 to 15.80 in GL and CL plots, respectively. Similarly, the concentration of exchangeable $\mathrm{K}\left(\mathrm{mg} \mathrm{kg}^{-1}\right)$ ranged from 6.22 to 9.69 in GL and CL plots, respectively. The concentrations of sediment associated $\mathrm{N}$ and $\mathrm{K}$ losses were significantly higher in CL than in GL. Generally, the average sediment-associated SOC export was not significantly different between the two land use types (Fig. 5). As shown in the figure, SOC export varied across the study period. Accordingly, significantly higher SOC export was recorded in CL compared to GL during 2007 and 2009. In 2008, however, SOC export was significantly higher in GL compared to CL.

Taking into account the total soil loss from experimental plots, GL significantly reduced nutrient losses. The highest average losses of total $\mathrm{N}\left(47.8 \mathrm{~kg} \mathrm{ha}^{-1}\right.$ year $\left.^{-1}\right), \mathrm{P}\left(0.59 \mathrm{~kg} \mathrm{ha}^{-1}\right.$ year $\left.^{-1}\right)$ and $\mathrm{K}\left(0.39 \mathrm{~kg} \mathrm{ha}^{-1}\right.$ year $\left.^{-1}\right)$ were recorded in CL (Table 5). On the contrary, the lowest average losses of total $\mathrm{N}\left(32.8 \mathrm{~kg} \mathrm{ha}^{-1}\right.$ year $\left.^{-1}\right), \mathrm{P}(0.39$
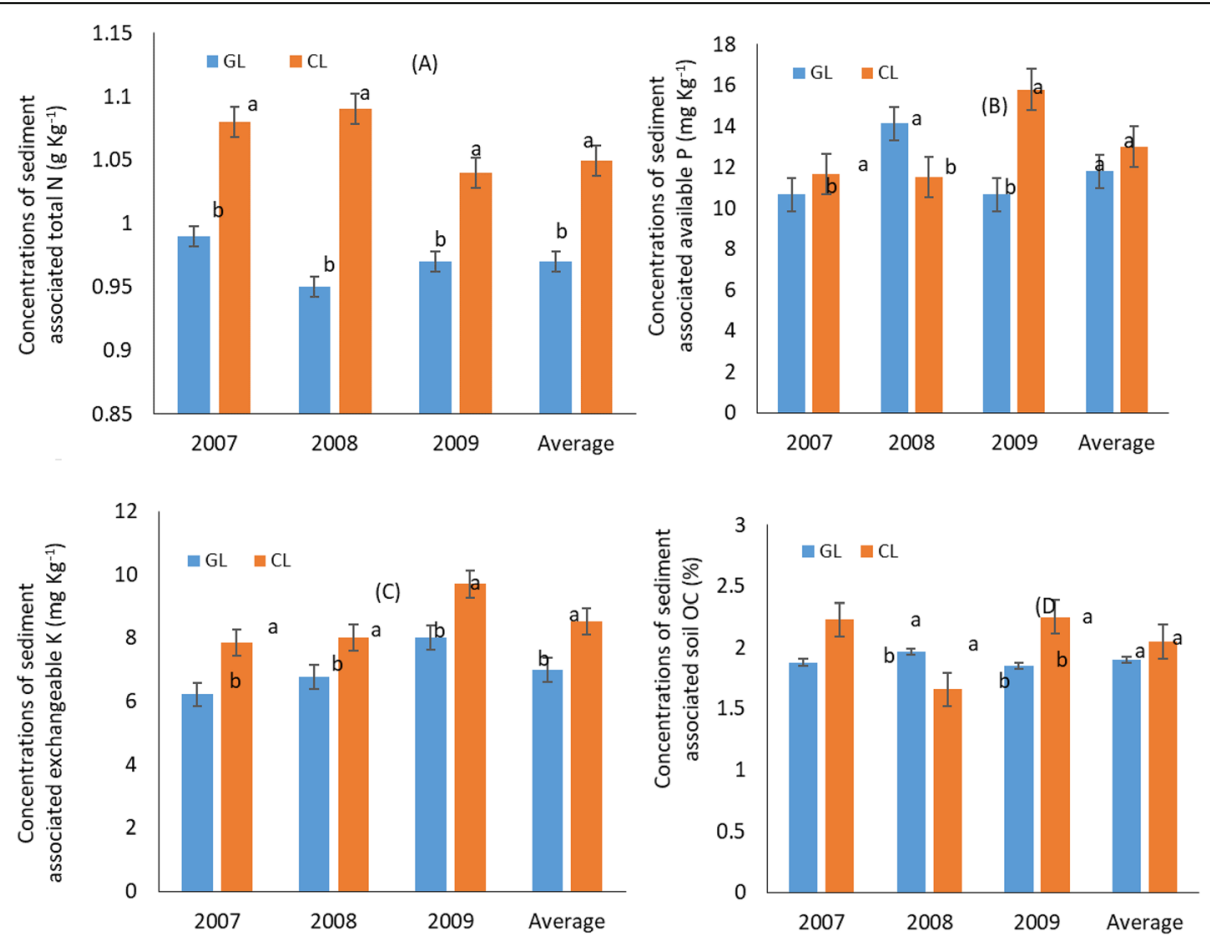

Fig. 5 Mean concentration of total nitrogen (N) (a), available phosphorus (P) (b), exchangeable Potassium (K) (c), and soil organic carbon (OC) (d) from the sediment leaving the experimental plots. Different letters in each year are significantly different at 0.05 level. GL grazing land, $\mathrm{CL}$ cultivated land. Error bars are standard errors of the means 
Table 5 Sediment associated mean annual losses of total N, available P, exchangeable K, and soil organic carbon (SOC) from the sediment leaving the runoff plots

\begin{tabular}{|c|c|c|c|c|c|}
\hline Year & Treatments & Total N (kg ha ${ }^{-1}$ year $\left.^{-1}\right)$ & Av. P (kg ha ${ }^{-1}$ year $\left.^{-1}\right)$ & Exch. K (kg ha ${ }^{-1}$ year $\left.^{-1}\right)$ & SOC $\left(\right.$ t ha $^{-1}$ year $\left.^{-1}\right)$ \\
\hline \multirow[t]{2}{*}{2007} & $\mathrm{GL}$ & $31.48^{b}$ & $0.34^{b}$ & $0.20^{b}$ & $0.60^{b}$ \\
\hline & $\mathrm{CL}$ & $46.43^{\mathrm{a}}$ & $0.50^{\mathrm{a}}$ & $0.34^{\mathrm{a}}$ & $0.96^{\mathrm{a}}$ \\
\hline \multirow[t]{2}{*}{2008} & GL & $31.82^{b}$ & $0.47^{b}$ & $0.23^{b}$ & $0.66^{b}$ \\
\hline & $\mathrm{CL}$ & $54.05^{a}$ & $0.57^{\mathrm{a}}$ & $0.40^{\mathrm{a}}$ & $0.82^{a}$ \\
\hline \multirow[t]{2}{*}{2009} & $\mathrm{GL}$ & $35.00^{b}$ & $0.36^{b}$ & $0.27^{b}$ & $0.62^{b}$ \\
\hline & $\mathrm{CL}$ & $42.92^{a}$ & $0.70^{a}$ & $0.43^{\mathrm{a}}$ & $1.00^{\mathrm{a}}$ \\
\hline \multirow[t]{2}{*}{ Average } & $\mathrm{GL}$ & $32.77^{b}$ & $0.39^{b}$ & $0.23^{b}$ & $0.63^{b}$ \\
\hline & $\mathrm{CL}$ & $47.8^{\mathrm{a}}$ & $0.59^{a}$ & $0.39^{\mathrm{a}}$ & $0.93^{\mathrm{a}}$ \\
\hline
\end{tabular}

Columns with different letters are significantly different at 0.05 level, GL grazing land, $C L$ cultivated land

$\left.\mathrm{kg} \mathrm{ha}^{-1} \mathrm{year}^{-1}\right)$, and $\mathrm{K}\left(0.23 \mathrm{~kg} \mathrm{ha}^{-1}\right.$ year $\left.^{-1}\right)$ were recorded in GL. Average losses $\left(\mathrm{t} \mathrm{ha}^{-1}\right.$ year $\left.^{-1}\right)$ of SOC were 0.63 and 0.93, from GL and CL plots, respectively. This indicates that GL reduced sediment-associated organic carbon losses by $32.3 \%$.

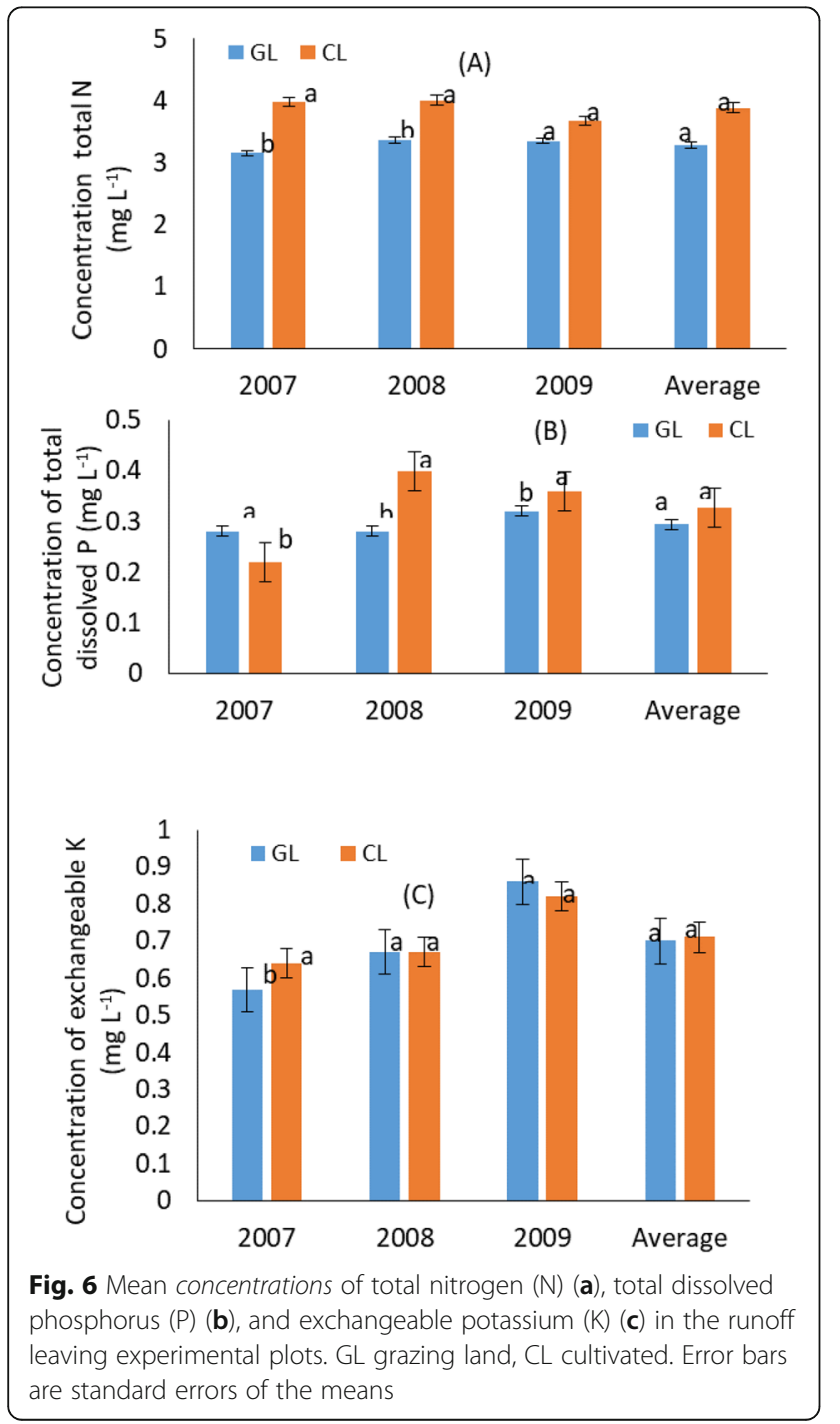

\section{Influence on runoff associated nutrient export}

The nutrient analysis of the runoff leaving the experimental plots showed that runoff water carries essential plant nutrients (N, P, K). Asshown in Fig. 6, the average concentrations of total $\mathrm{N}\left(\mathrm{mg} \mathrm{L}^{-1}\right)$ in the runoff were 3.29 and 3.89 from GL and CL plots, respectively. The average concentrations of $\mathrm{P}\left(\mathrm{g} \mathrm{L}^{-1}\right)$ in the runoff were 0.29 and 0.33 from GL and CL plots, respectively. Similarly, the average concentrations of exchangeable $\mathrm{K}$ (mg $\mathrm{L}^{-1}$ ) in the runoff water were also 0.70 and 0.71 , respectively. The results showed that there was no significant difference in the average concentrations of $\mathrm{K}, \mathrm{N}$, and $\mathrm{P}$ between the treatments (Fig. 6).

Table 6 presents the annual nutrient losses from runoff by taking into account the average nutrient concentration in the runoff and the total runoff volume. As compared to the CL, GL reduced runoff-associated losses of total N, P, and $K$ by 8,5 , and $8 \%$, respectively (Table 6 ).

Although there was no significant difference in concentrations of $\mathrm{P}$ and $\mathrm{K}$ among the treatments, annual losses were significantly different. This might be due to the fact that the total annual runoff volume was higher in GL as compared to CL. P losses from the plots are not economically important, but it will have a negative

Table 6 Runoff associated annual losses $\left(\mathrm{kg} \mathrm{ha}^{-1}\right.$ year $\left.{ }^{-1}\right)$ of total nitrogen, available phosphorus (P), and exchangeable potassium (K)

\begin{tabular}{lllll}
\hline Year & Treatments & Total nitrogen & Available P & Exchangeable K \\
\hline 2007 & $\mathrm{GL}$ & $7.43^{\mathrm{a}}$ & $0.66^{\mathrm{a}}$ & $1.34^{\mathrm{a}}$ \\
& $\mathrm{CL}$ & $8.72^{\mathrm{a}}$ & $0.48^{\mathrm{a}}$ & $1.40^{\mathrm{a}}$ \\
2008 & $\mathrm{GL}$ & $10.92^{\mathrm{b}}$ & $0.91^{\mathrm{b}}$ & $2.18^{\mathrm{a}}$ \\
& $\mathrm{CL}$ & $12.25^{\mathrm{a}}$ & $1.22^{\mathrm{a}}$ & $2.05^{\mathrm{a}}$ \\
2009 & $\mathrm{GL}$ & $9.55^{\mathrm{a}}$ & $0.91^{\mathrm{a}}$ & $2.45^{\mathrm{a}}$ \\
& $\mathrm{CL}$ & $9.24^{\mathrm{a}}$ & $0.90^{\mathrm{a}}$ & $2.06^{\mathrm{a}}$ \\
\multirow{2}{*}{ Average } & $\mathrm{GL}$ & $9.30^{\mathrm{a}}$ & $0.83^{\mathrm{a}}$ & $1.84^{\mathrm{a}}$ \\
& $\mathrm{CL}$ & $10.07^{\mathrm{a}}$ & $0.87^{\mathrm{a}}$ & $1.99^{\mathrm{a}}$ \\
\hline
\end{tabular}

Columns with the same letters are not significantly different at 0.05 level, $C L$ cultivated land, GL grazing land 
impact on the downstream water bodies because the concentration of $\mathrm{P}$ in the runoff is in excess of the threshold (>0.1 $\mathrm{mg} \mathrm{L}^{-1}$ ) (Wang and Sharply 2014; Kleinman et al. 2011). The results of the repeated ANOVA show that losses of total nitrogen, available phosphorus, and exchangeable potassium were not significantly different over the years (Table 7).

\section{Total nutrient export}

The average total sediment and runoff associated nutrient export are presented in Table 8 . As shown in the table, $42.1 \mathrm{~kg} \mathrm{ha}^{-1}$ year $^{-1} \mathrm{~N}, 1.2 \mathrm{~kg} \mathrm{ha}^{-1}$ year $^{-1} \mathrm{P}$, and 2.1 $\mathrm{kg} \mathrm{ha}^{-1}$ year $^{-1} \mathrm{~K}$ were lost from GL. However, $57.9 \mathrm{~kg}$ $\mathrm{ha}^{-1}$ year $^{-1} \mathrm{~N}, 1.5 \mathrm{~kg} \mathrm{ha}^{-1}$ year $^{-1} \mathrm{P}$, and $2.4 \mathrm{~kg} \mathrm{ha}^{-1}$ year $^{-1}$ $\mathrm{K}$ were lost from CL. Studies elsewhere in Ethiopia showed that up to $60 \mathrm{~kg} \mathrm{ha}^{-1}$ year $^{-1}$ nitrogen and $150 \mathrm{~kg}$ $\mathrm{ha}^{-1}$ year $^{-1}$ phosphorus were removed with soil erosion from cultivated lands (Habtegebrial et al. 2007). Girmay et al. (2019) also reported 32.5, 0.2, and $5.3 \mathrm{~kg} \mathrm{ha}^{-1}$ year $^{-1}$ of total $\mathrm{N}$, available $\mathrm{P}$, and available $\mathrm{K}$ losses, respectively, from cultivated lands. Similarly, 9, 0.1, and $1.2 \mathrm{~kg} \mathrm{ha}^{-1}$ year $^{-1}$ of $\mathrm{N}$, available $\mathrm{P}$, and available $\mathrm{K}$, respectively, were lost from grazing lands (Girmay et al. 2009).

In terms of fertilizers, $5.8 \mathrm{~kg}$ DAP, 89.2 urea, and 4.1 muriate of potash (MoP) were lost from GL. Similarly, 7 $\mathrm{kg}$ DAP, $123.1 \mathrm{~kg}$ urea, and $4.8 \mathrm{~kg} \mathrm{MoP}$ were lost from CL. In general, the total nutrient loss from GL was lower compared with $\mathrm{CL}$. However, the absolute nutrient losses from GL and CL were still high. Hence, there is a need to implement appropriate land management practices in both GL and CL. This implies that soil erosion increases replacement cost for fertilizers in the studied watershed.

\section{Conclusions and implications}

This study highlights the effects of cultivation and grazing on runoff, soil erosion, and soil nutrient losses in the central highlands of Ethiopia. The results showed that grazing land reduced soil erosion and nutrient loss compared with cultivated land. However, the actual losses

Table 7 Mean annual losses of total nitrogen (N), available phosphorus (P), and exchangeable potassium (K) in grazing land $(\mathrm{GL})$ and cultivated land $(\mathrm{CL})$ over the three study years $\left(\mathrm{kg} \mathrm{ha}^{-1}\right.$ year $^{-1}$ )

\begin{tabular}{|c|c|c|c|c|c|c|}
\hline \multirow[b]{2}{*}{ Year } & \multicolumn{2}{|c|}{ Total N } & \multicolumn{2}{|c|}{ Available P } & \multicolumn{2}{|c|}{ Exchangeable K } \\
\hline & $\overline{G L}$ & $\mathrm{CL}$ & $\overline{\mathrm{GL}}$ & $\mathrm{CL}$ & $\overline{G L}$ & $\mathrm{CL}$ \\
\hline 2007 & 38.91 & 55.15 & 1.00 & 0.98 & 1.54 & 1.74 \\
\hline 2008 & 42.74 & 66.30 & 1.38 & 1.79 & 2.41 & 2.45 \\
\hline 2009 & 44.55 & 52.16 & 1.27 & 1.60 & 2.72 & 2.49 \\
\hline$p$ value & 0.185 & 0.254 & 0.062 & 0.120 & 0.235 & 0.089 \\
\hline
\end{tabular}

Columns with different letters are significantly different at 0.05 level, $G L$ grazing land, CL cultivated land
Table 8 Soil erosion associated losses of nitrogen $(\mathrm{N})$, phosphorus (P), and potassium (K) from grazing land (GL) and cultivated land $(\mathrm{CL})$ in the Galesa watershed of Ethiopian highlands (kg ha ${ }^{-1}$ year ${ }^{-1}$ )

\begin{tabular}{llll}
\hline Nutrients & $\mathrm{GL}$ & $\mathrm{CL}$ & Average \\
\hline $\mathrm{N}$ & 42.07 & 57.87 & 49.97 \\
$\mathrm{P}$ & 1.22 & 1.46 & 1.34 \\
$\mathrm{~K}$ & 2.22 & 2.23 & 2.23 \\
$\mathrm{~N}$ in the form of urea & 89.18 & 123.08 & 106.13 \\
$\mathrm{P}$ in the form of DAP & 5.81 & 6.95 & 6.38 \\
$\mathrm{~K}$ in the form of muriate of potash & 4.14 & 4.76 & 4.45 \\
\hline
\end{tabular}

from grazing land are still high. This indicates that physical erosion control measures as well as planting multipurpose trees and grasses are needed to reduce runoff, soil, and nutrient losses from both grazing and cultivated lands. This study does not support the claim that de facto grazing system in Ethiopia signifies a serious soil erosion problem and reduces land productivity. Mixed crop and livestock production systems in the Ethiopian highlands are important and have been practicing hand in hand for centuries. Hence, better management of grazing and cultivated lands can reduce soil loss and enhance sustainable intensifications of crop-livestock farming system in the highlands of Ethiopian.

\section{Limitation of the study}

In order to compare grazing and cultivated lands, fertilizer was not applied in both land use types. The actual nutrient export could have been higher in cultivated land compared with grazing land and this implies that the study might underestimate the nutrient export from cultivated lands. This study was also carried out in small runoff plots of $210 \mathrm{~m}^{2}$ each. Such small plots might overestimate runoff, soil loss, and nutrient exports compared with watershed level measurements. Since runoff plots were placed adjacent to croplands, grazing was somehow controlled and might not represent the free grazing practices in the area.

\section{Acknowledgements}

The authors gratefully acknowledge the Ethiopian Institute of Agricultural Research (EIAR) and the CGIAR research program on Water, Land, and Ecosystems (WLE) for funding this research. We are grateful for two anonymous referees who offered substantial comments that have helped to improve the quality of this manuscript.

\section{Authors' contributions}

ZA conducted the field research, analyzed the data, and drafted the manuscript. LT interpreted the results and fully participated in the whole process of the write-up of the manuscript. Both authors revised the manuscript and read and approved the final submission. DTD revised the manuscript and prepared the map of study area. All authors read and approved the final manuscript. 


\section{Authors' information}

Zenebe Adimassu a research scientist at the International Water Management Institute (IWMI). His research interest includes land degradation, land management, conservation agricultures, ecosystem services, climate change, and irrigation. Lulseged Tamene is a senior scientist working for the International Center for Tropical Agriculture (CIAT) based in Ethiopia. His research includes soil management, geomorphology, landscape restoration and management, geospatial analysis, and decision support system for land restoration. Degefie T. Degefie is a postdoctoral scientist at the Water and Land Resources Center (WRC), in Addis Ababa. His research interest is geospatial analysis of land and water resources.

\section{Funding}

This study did not receive any external funding.

\section{Ethics approval and consent to participate}

Not applicable.

\section{Consent for publication}

Not applicable.

\section{Competing interests}

On behalf of all authors, the corresponding author states that there are no conflicts of interest.

\section{Author details}

'International Water Management Institute (IWMI), Addis Ababa, Ethiopia.

${ }^{2}$ International Center for Tropical Agriculture (CIAT), Addis Ababa, Ethiopia.

${ }^{3}$ Water and Land Resource Center, Addis Ababa, Ethiopia.

\section{Received: 4 November 2019 Accepted: 13 April 2020}

\section{Published online: 14 May 2020}

\section{References}

Adimassu Z, Alemu G, Tamene L (2019) Effects of tillage and crop residue management on runoff, soil loss and crop yield in the humid highlands of Ethiopia. Agric Syst 168:11-18

Adimassu Z, Amare G, Getachew A, Mekonnen K, Mesfin T, Amede T, German L (2008) Watershed-based soil and water conservation experiences in Ethiopian highlands. In: Adimassu Z, Kindu M, Yohannes G (eds). Working with Communities on Integrated Natural Resources Management, EIAR

Adimassu Z, Haile N (2011) Runoff, soil loss and their relationships under different land uses in the central highland of Ethiopia. Ethiopian J App Sci Tech 2:3949

Alemayehu M, Amede T, Böhme M, Peters KJ (2013) Collective management on communal grazing lands: its impact on vegetation attributes and soil erosion in the upper Blue Nile basin, northwestern Ethiopia. Livest Sci 157:271-279

Allison LE (1965) Organic carbon. In: Black CA (ed) Methods of soil analysis. Part II: Chemical and microbiological properties. America Society of Agronomy, pp 1367-1376

Asadu CLA (1996) Soil management for conservation and sustainable rice production in an irrigated area of eastern Nigeria. Outl Agric 25(3):151-156

Belayneh M, Yirgu T, Tsegaye D (2019) Effects of soil and water conservation practices on soil physicochemical properties in Gumara watershed, Upper Blue Nile Basin, Ethiopia. Ecol Process 8:36

Bezabih M, Pellikaan WF, Tolera A, Khan NA, Hendriks WH (2014) Nutritional status of cattle grazing natural pasture in the Mid Rift Valley grasslands of Ethiopia measured using plant cuticular hydrocarbons and their isotope enrichment. Livest Sci 161:41-52

Blaikie P (1985) Political economy of soil erosion in developing countries. Longman Development Studies, New York

Bosshart U (1997) Catchment discharge and suspended sediment transport as indicators of physical soil and water conservation in the Minchet Catchment, Anjeni Research Unit. Soil Conservation Research Report 40. Berne, Switzerland: University of Berne.

Bray RH, Kurtz LT (1945) Determination of total, organic, and available forms of phosphorous in soils. Soil Sci 59:39-45

Bremner JM (1965) Total nitrogen. In: Black CA (Ed.), Methods of soil analysis, Agronomy No. 9. Part 2. American Society of Agronomy, Madison, WI.

Central Statistical Authority (CSA) (2012) Statistical abstract of Ethiopia. Central Statistical Authority, Addis Ababa, Ethiopia
Cheung WH, Senay GB, Singh A (2008) Trends and spatial distribution of annual and seasonal rainfall in Ethiopia. Int J Climatol 28:1723-1734

Collins AL, Walling DE, Sichingabula HM, Leeks GJL (2001) Using ${ }^{137} \mathrm{CS}$ measurements to quantify soil erosion and redistribution rates for areas under different land use in the Upper Kaleya River basin, southern Zambia. Geoderma 104:299-323

Descheemaeker K, Nyssen J, Poesen J, Haile M, Muys B, Raes D, Moeyersons J, Deckers J (2006) Soil and water conservation through forest restoration in exclosures of the Tigray highlands. J Drylands 1:118-133

Gebreegziabher T, Nyssen J, Govaerts B, Getnet F, Behailu M, Haile M, Deckers J (2008) Contour furrows for in situ soil and water conservation, Tigray, northern Ethiopia. Soil Tillage Res 103:257-264

Gebresamuel GB, Singh R, Dick O (2010) Land-use changes and their impacts on soil degradation and surface runoff of two catchments of Northern Ethiopia. Acta Agr Scand B Plant Soil Sci 60:211-226

Gebreselassie S, Kirui OK, Mirzabaev A (2016) Economics of land degradation and improvement in Ethiopia. In: Nkonya E, Mirzabaev A, von Braun J (eds). Economics of Land Degradation and Improvement - A Global Assessment for Sustainable Development, https://doi.org/10.1007/978-3-319-19168-3_14. pp 401-430

German L (2006) Moving beyond component research in mountain regions: operationalizing systems integration at farm and landscape scales. J Mountain Sci 3:287-304

German L, Shenkut A, Adimassu Z (2008) Managing linkages between communal rangelands and private cropland in the highlands of Eastern Africa: contributions to participatory integrated watershed management. Soc Natural Res 21:134-151

Gessesse GD, Mansberger R, Klik A (2015) Assessment of rill erosion development during erosive storms at Angereb watershed, Lake Tana sub-basin in Ethiopia. J Mountain Sci 12:49-59

Girmay G, Singh BR, Nyssen J, Borrose T (2009) Runoff and sediment-associated nutrient losses under different land uses in Tigray, Northern Ethiopia. J Hydrol 376:70-80

Habtegebrial K, Singh BR, Haile M (2007) Impact of tillage and nitrogen fertilization on yield, nitrogen use efficiency of tef (Eragrostis tef (Zucc.) Trotter) and soil properties. Soil Tillage Res 94:55-63

Harweg K, Ludi E (1999) The performance of selected soil and water conservation measures-case studies from Ethiopia and Eritrea. Catena 36:99-114

Heron EJ (1990) Collection and preparation of soil and water samples from Cardigan runoff installation. CSIRO Division of Soil Technical Memorandum, No. 15

Hudson NW (1993) Field measurement of soil erosion and runoff. FAO Soil Bulletin, No. 68, pp 139, Rome

Hurni H (1989) Degradation and conservation of the resource in the Ethiopian highlands. Mount Res Develop 8:123-130

Hurni H (1993) Land degradation, famine, and land resource scenarios in Ethiopia. In: Pimentel D (ed). World Soil Erosion and Conservation. Cambridge Studies in Applied Ecology and Resource Management. Cambridge, UK: Cambridge University Press, pp 27-61

Hurni H, Messerli B (1981) Mountain research for conservation and development in Simen, Ethiopia. Mount Res Develop 1(1):49-54

Kleinman PJA, Sharpley AN, McDowell RW, Flaten DN, Buda AR, Tao L, Bergstrom L, Zhu Q (2011) Managing agricultural phosphorus for water quality protection: principles for progress. Plant Soil 349:169-182

Kothyari BP, Verma PK, Joshi BK, Kothyari UC (2004) Rainfall-runoff-soil and nutrient loss relationships for plot size areas of bhetagad watershed in Central Himalaya, India. J Hydrol 293:137-150

Megersa B, Markemann A, Angassa A, Zarate AV (2013) The role of livestock diversification in ensuring household food security under a changing climate in Borana, Ethiopia. Food Security 6:15-28

Mekuria W, Veldkamp E, Haile H, Nyssen J, Muys B, Gebrehiwot K (2007) Effectiveness of exclosures to restore degraded soils as a result of overgrazing in Tigray, Ethiopia. J Arid Environ 69:270-284

Melak Y, Angassa A, Abebe A (2019) Effects of grazing intensity to water source on grassland condition, yield and nutritional content of selected grass species in Northwest Ethiopia. Ecol Process 8:12

Meten M, Bhandary NP, Yatabe R (2015) GIS-based frequency ratio and logistic regression modelling for landslide susceptibility mapping of Debre Sina area in central Ethiopia. J Mountain Sci 12:1355-1372

Miheretu BA, Yimer AB (2017) Determinants of farmers' adoption of land management practices in Gelana sub-watershed of Northern highlands of Ethiopia. Ecol Process 6:19 
Mwendera EJ, Saleem MAM (1997) Abstract.Infiltration rates, surface runoff, and soil loss as influenced by grazing pressure in the Ethiopian highlands. Soil Use Manage 13:29-35

Mwendera EJ, Saleem MAM, Dibabe A (1997) The effect of livestock grazing on surface runoff and soil erosion from sloping pasture lands in the Ethiopian highlands. Aus J Exp Agri 37:421-430

Nyssen J, Haile M, Moeyersons J, Poesen J, Deckers J (2000) Soil and water conservation in Tigray (Northern Ethiopia): the traditional technique and its integration with introduced techniques. Land Degrad Dev 11:199-208

Nyssen J, Poesen J, Mitiku H, Moeyersons J, Deckers J, Hans H (2009) Effects of land use and land cover on sheet and rill erosion rates in the Tigray highlands, Ethiopia. Z Geomorphol 53:171-197

Nyssen J, Poesen J, Moeyersons J, Deckers J, Haile M, Lang A (2004) Human impact on the environment in the Ethiopian and Eritrean highlands-a state of the art. Earth Sci Rev 64:273-320

Nyssen J, Vandenreyken H, Poesen J, Moeyersons J, Deckers J, Mitiku H, Salles C, Govers G (2005) Rainfall erosivity and variability in the Northern Ethiopian Highlands. J Hydrol 311:172-187

Rao KPC, Steenhuis TS, Cogle AL, Srinivasan ST, Yule DF, Smith GD (1998) Rainfall infiltration and runoff from an Alfisol in semi-arid tropical India. Soil Tillage Res 48:61-69

Shiferaw B, Holden S (1999) Soil erosion and smallholders' conservation decisions in the highlands of Ethiopia. World Dev 27:739-752

Shiferaw B, Holden S (2000) Policy instruments for sustainable land management: the case of highland smallholders in Ethiopia. Agric Econ 22:217-232

Stroosnijder L (2005) Measurement of Erosion: Is it possible? Catena 64:162-173

Tamene L, Adimassu Z, Ellison J, Yaekob T, Woldearegay K, Mekonnen K, Thorne P, Le QB (2017) Mapping soil erosion hotspots and assessing the potential impacts of land management practices in the highlands of Ethiopia. Geomorphology 292:153-163

Tamene L, Park S, Dikau R, Vlek PLG (2006) Analysis of factors determining sediment yield variability in the highlands of Northern Ethiopia. Geomorphology 76:76-91

Taye G, Poesen J, Van Wesemael B, Vanmaercke M, Teka D, Deckers J, Goosse T, Maetens W, Nyssen J, Hallet V, Haregeweyn N (2013) Effects of land use, slope gradient, and soil and water conservation structures on runoff and soil loss in semi-arid northern Ethiopia. Phys Geogr 34:236-259

Terefe H, Argaw M, Tamene L, Mekonnen K, Rechal J, Solomon D (2020) Effects of sustainable land management interventions on selected soil properties in Geda watershed, central highlands of Ethiopia. Ecol Process 9:14

Thornes JB (2007) Modelling soil erosion by grazing: recent developments and new approaches. Geogr Res 45:13-26

Tolessa T, Gessese H, Tolera M, Kidane M (2018) Changes in ecosystem service values in response to changes in landscape composition in the central highlands of Ethiopia. Environ Process 5:483-501

Walle S, Chantawarangul K, Nontananandh S, Jantawat S (2006) Effectiveness of grass strips as barrier against runoff and soil loss in Jijiga area, northern part of Somali Region, Ethiopia. Kasetsart J 40:549-558

Wang XY, Li LQ, Yang MY, Tian JL (2003) Spatial distribution of soil erosion on different utilization soils in Yangou watershed by using ${ }^{137} \mathrm{Cs}$ tracer. J Soil Water Conserv 17:74-77

Worku A, Hailu R (1999) Effect of tillage practices and cropping systems on runoff and soil loss at Ginch. In: Proceedings of the Fourth Conference of the Ethiopian Society of Soil Sciences (ESSS). Addis Ababa, Ethiopia, 26-27, 1998, Institute of Agricultural Research (IAR). pp 39-43

Woyessa YE, Bennie ATP (2007) Tillage-crop residue management and rainfallrunoff relationships for the Alemaya catchment in Eastern Ethiopia. South African J Plant Soil 24:8-15

Yaekob T, Tamene L, Gebrehiwot SG, Demissie SS, Adimassu Z, Woldearegay K Mekonnen K, Amede T, Abera W, Recha JW, Solomon D, Thorne P (2020) Assessing the impacts of different land uses and soil and water conservation interventions on runoff and sediment yield at different scales in the central highlands of Ethiopia. Renew Agr Food Syst:1-15

\section{Publisher's Note}

Springer Nature remains neutral with regard to jurisdictional claims in published maps and institutional affiliations.

\section{Submit your manuscript to a SpringerOpen ${ }^{\circ}$ journal and benefit from:}

- Convenient online submission

- Rigorous peer review

- Open access: articles freely available online

- High visibility within the field

- Retaining the copyright to your article

Submit your next manuscript at $\boldsymbol{\nabla}$ springeropen.com 